\title{
MAHRAM DAN KAWIN SESUKU DALAM KONTEKS HUKUM ISLAM (Kajian Tematik Ayat-Ayat Hukum Keluarga)
}

\author{
Arisman \\ Fakultas Syari'ah dan Hukum UIN Sultan Syarif Kasim Riau \\ Jl. Raya Pekanbaru-Sungai Pagar Pekanbaru Riau \\ e-mail: arisman@uin-suska.ac.id
}

\begin{abstract}
Mahram is an important problem in Islam because it can influence the behavior, halal and haram. In addition, mahram is a wise decision from Allah the almighty and it is also a perfection of this religion which manages all aspects of life. As a result, it is a must for us to know whom belongs to mabram and his right. Futhermore, mahram also reached the problem of in-tribe married. The problem is whether it is considered as an opposit opinion toward the existence of mabram or not. This problem is always debated by many religion experts and it has emerged many different groups of schools and also one punished another who probibited in-tribe married case. As a conclusion the writer declared that this problem is not part of daruriyyat, but it is just a hajizyat category. In another word we can say that in-tribe married is allowed in Islam.
\end{abstract}

Kata kunci: mahram, kawin sesuku, Hukum Islam

\section{PENDAHULUAN}

P erkawinan dalam pandangan Islam bukan hanya urusan keluarga dan masalah budaya, bukan pula sekadar urusan perdata semata, tetapi yang sangat penting juga merupakan masalah agama, oleh sebab itu perkawinan dilakukan adalah untuk memenuhi perintah Allah dan Sunnah Nabi dan dilaksanakan sesuai dengan petunjuk Allah dan petunjuk Nabi. Dari keterangan tersebut dapat kita lihat bahwa dalam hukum Islam perkawinan harus dilaksanakan berdasarkan petunjuk Allah dan petunjuk Nabi, (Amir Syarifuddin, 2007: 48). Namun pada kenyataannya masih banyak daerah-daerah di Indonesia yang masih menggunakan tradisi adat dalam hal perkawinan, tentu hal ini bertentangan dengan prinsip Islam padahal Indonesia adalah negara yang penduduknya mayoritas beragama Islam.

Menurut Hukum Islam terdapat ketentuan-ketentuan bahwa orang tidak boleh mengikat tali perkawinan dan pertalian yang disebut muhrim, disebabkan pertalian darah, pertalian perkawinan dan pertalian sepersusuan.

Begitu jelas Islam menjelaskan tentang hakekat dan arti penting perkawinan, bahkan dalam beberapa undang-undang masalah perkawinan diatur secara khusus. Seperti, Undang-undang No. 1 Tahun 1974 tentang perkawinan, Kompilasi Hukum Islam, Peraturan Pemerintah No. 9 tahun 1975 dan lainlain. Dalam hukum perkawinan Islam dikenal sebuah asas yang disebut selektivitas. Artinya bahwa, seseorang 
ketika hendak melangsungkan pernikahan terlebih dahulu harus menyeleksi dengan siapa ia boleh menikah dan dengan siapa ia terlarang untuk menikah (Amiur Nuruddin, 2004: 144). Hal ini untuk menjaga agar pernikahan yang dilangsungkan tidak melanggar aturan-aturan yang ada. Terutama bila perempuan yang hendak dinikah ternyata terlarang untuk dinikahi, yang dalam Islam dikenal dengan istilah mahram (orang yang haram dinikahi). Perkawinan sesuku menurut adat Minangkabau merupakan sesuatu hal yang dilarang dikarenakan beberapa alasan-alasan tertentu. Menikah sesuku menurut logika hukum Minangkabau tidak baik. Sanksinya jika dilanggar adalah sanksi moral, dikucilkan dari pergaulan, dan lain-lainnya. Bukan saja pribadi orang yang mengerjakannya, tapi keluarga besar pun mendapat sanksinya. Namun dalam islam apakah kawin sesuku dibolehkan atau tidak.

Berdasarkan hal di atas penulis perlu mengkaji tentang mahram dan kawin sasuku dalam konteks Hukum Islam (Kajian Tematik Ayat-ayat Hukum Keluarga).

\section{METODE PENELITIAN}

Tulisan ini menggunakan metode kajian kepustakaan (library research) yang bersifat kualitatif. Pembahasan yang dikemukakan didasari bahan-bahan yang diteliti melalui dalil-dalil al-Qur'an dan Sunnah, kitab-kitab figh dan tafsir. Dari kitab-kitab tersebut dikutip berbagai pendapat dan argumentasi para ulama beserta dalil-dalil yang mereka kemukakan, kemudian diambil suatu kesimpulan yang dapat dipahami seperti yang tertera dalam tulisan ini.

\section{PEMBAHASAN}

\section{Ayat-ayat yang berbicara tentang Mahram dan Penafsirannya}

Dalam kamus Al-Munawwir kata

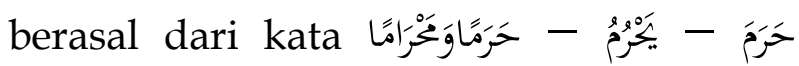
yang berarti mencegah. Sedangkan sendiri berarti yang haram atau terlarang. Al-Munawwir; 1997: 256-257).

Mahram Menurut istilah ada beberapa pendapat:

a. Abdul Barr Rahimahullah, adalah lakilaki yang haram bagi wanita karena sebab nasab seperti bapak dan saudara laki-lakinya atau sebab pernikahan seperti suami, bapak suami (mertua) dan anak laki-laki suami (anak tiri) atau anak susuan, saudara sesusuan dan karena sebab yang lain.

b. Al-Hafidz, mahram perempuan adalah orang yang diharamkan baginya atas dasar ikatan (pernikahan) kecuali ibu hasil hubungan badan yang syubhat dan wanita yang dilaknat. (Kitab Fathul Barri, jil. 9: 332).

c. Ibnu Qudamah rahimahullah adalah semua orang yang haram untuk dinikahi selama-lamanya karena sebab nasab, persusuan dan pernikahan, seperti bapaknya, anaknya atau saudara laki-lakinya karena sebab nasab atau sepersusuan. (Abdul Karim Zaidan, tt: 148).

d. Ibnu Atsir Rahimahullah adalah yang diharamkan menikah dengan sanak keluarganya seperti bapak, anak, saudara laki-laki, pamannya atau yang 
lainnya yang masih memiliki ikatan mahram.

e. Muhammad Khasyad Rahimahullah adalah seorang yang haram menikah atas dasar ikatan karena sebab pernikahan, nasab, persusuan atau sebab yang lain. (Muhammad Khasyad, 1994: 142).

f. Syaikh Shaleh Al-Fauzan rahimahullah adalah semua orang yang haram dinikahi selama-lamanya karena sebab nasab seperti bapak, anak, dan saudaranya atau dari sebab-sebab pernikahan yang lain seperti saudara sepersusuannya, ayah ataupun anak tirinya.

Jadi definisi mahram secara keseluruhan adalah larangan atau pengharaman yang berkaitan dengan hukum misalnya; pernikahan, safar, batasan aurat serta hukum berjabat tangan, dan lain-lain.

Ada beberapa ayat yang menjelaskan tentang mahram, antara lain:

Ayat pertama: Sūrah an-nisā' ayat 22:

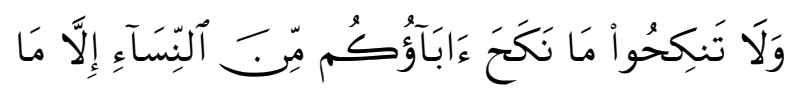

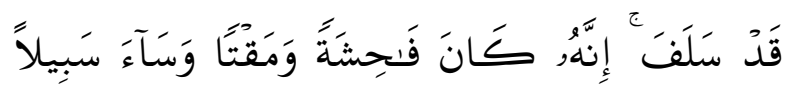

"Dan janganlah kamu kawini wanitawanita yang telah dikawini oleh ayahmu, terkecuali pada masa yang telah lampau. Sesungguhnya perbuatan itu Amat keji dan dibenci Alloh dan seburuk-buruk jalan (yang ditempuh)". (Q.S. An-Nisa [4]: 22.

Ayat kedua, Sūrah an-Nisā': 23 -24:

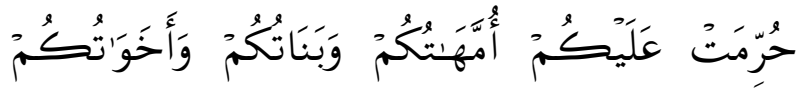

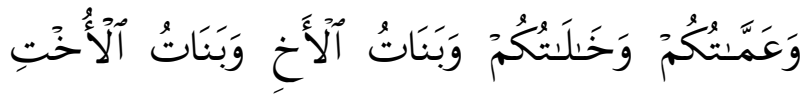

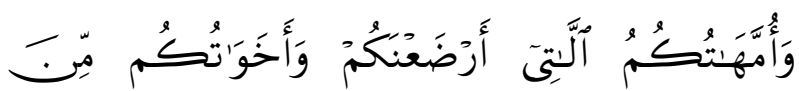

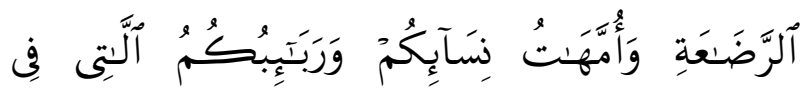

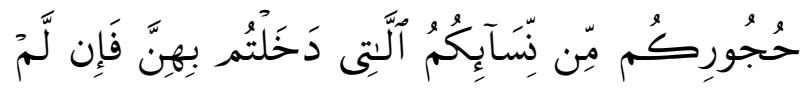

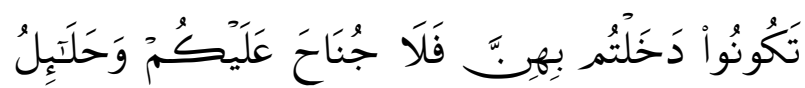

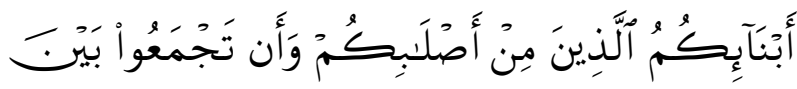

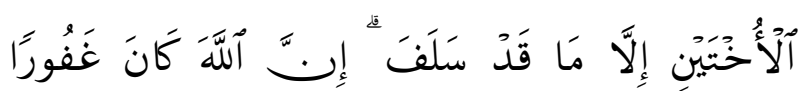

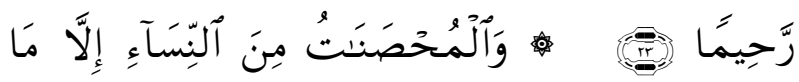

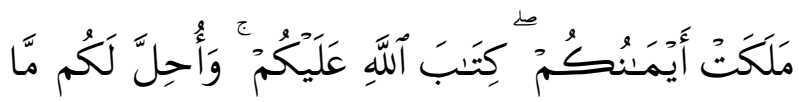

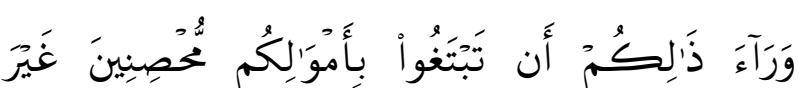

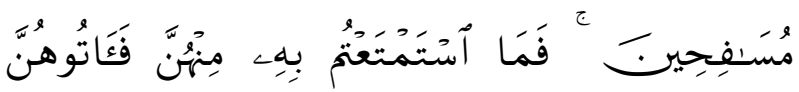

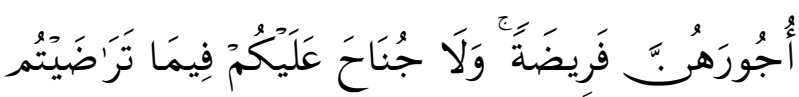

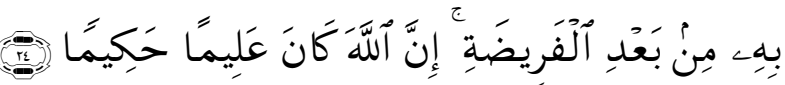

"Diharamkan atas kamu (mengawini) ibuibumu; anak-anakmu yang perempuan; saudara-saudaramu yang perempuan, saudara-saudara bapakmu yang perempuan; saudara-saudara ibumu yang perempuan; anak-anak perempuan dari saudara-saudaramu yang laki-laki; anakanak perempuan dari saudara-saudaramu yang perempuan; ibu-ibumu yang menyusui kamu; saudara perempuan sepersusuan; ibu-ibu isterimu (mertua); anak-anak isterimu yang dalam 
pemeliharaanmu dari isteri yang telah kamu campuri, tetapi jika kamu belum campur dengan isterimu itu (dan sudah kamu ceraikan), Maka tidak berdosa kamu mengawininya; (dan diharamkan bagimu) isteri-isteri anak kandungmu (menantu); dan menghimpunkan (dalam perkawinan) dua perempuan yang bersaudara, kecuali yang telah terjadi pada masa lampau; Sesungguhnya Alloh Maha Pengampun lagi Maha Penyayang. Dan (diharamkan juga kamu mengawini) wanita yang bersuami, kecuali budak-budak yang kamu miliki (Alloh telah menetapkan hukum itu) sebagai ketetapan-Nya atas kamu. Dan dihalalkan bagi kamu selain yang demikian (yaitu) mencari isteri-isteri dengan hartamu untuk dikawini bukan untuk berzina. Maka isteri-isteri yang telah kamu nikmati (campuri) di antara mereka, berikanlah kepada mereka maharnya (dengan sempurna), sebagai suatu kewajiban; dan tiadalah mengapa bagi kamu terhadap sesuatu yang kamu telah saling merelakannya, sesudah menentukan mahar itu. Sesungguhnya Alloh Maha mengetahui lagi Maha Bijaksana". (Q.S. An-Nisa [4]: 23-24).

\section{Penjelasan beberapa kata:}

: : Yang telah lalu, yaitu orangorang yang terdahulu dari kalangan orang tua dan karib kerabat.

في القبح : Menurut Bahasa yaitu (puncaknya kejelekan dalam arti sangat jelek). Disebut dengan fähisyah, karena merupakan puncak dari kejelekan.

: : Arti asal dari maqta adalah kebencian, yaitu sesuatu yang tidak disenangi/dibenci menurut rasio yang sehat.

: Cara/jalan yang keji dan tercela yang biasa mereka tempuh pada masa jahiliyah.

: : Bentuk plural/jamak dari ربيية, yaitu anak perempuan dari suami yang lain (anak tiri). Dinamai dengan rabāib karena suami mendidik dan membesarkannya

حلائل : Yaitu istri-istri, dan ia merupakan bentuk plural dari kata حليلة Dinamai demikian karena kedua suami istri tersebut menjadi halal satu sama lain.

: Kata-kata ihshān atau yang seakar kata dengan itu, pengertian dalam al-Qur'an tidak lebih dari empat arti : alTajawwuj, al-Islām, al-iffah, dan al-Hurriyah. Tetapi, maksud dalam ayat ini adalah wanitawanita yang memiliki suami (bersuami).

: : : : : : : dari perbuatan keji dan mesum.

: al- sifah wa al-musäfahat artinya adalah orang yang berbuat dosa dan kesalahan, secara etimologi kata ini mempunyai arti mengalirkan/ menumpahkan, karena tujuan orang yang berzina tiada lain adalah menumpahkan spermanya. (Muhammad 'Ali Ash-Shobunny: tt: 446-447). 
Sebab-sebab Turunnya ayat-ayat tentang Mahram

\section{Sūrah an-Nisā: 22}

Menurut Imam Jalaludin al-Suyuti (1422: 74), Dikemukakan oleh Ibnu Abi Hatim, al-Faryabi dan Ath-Thabrani yang bersumber dari 'Adiy bin Tsabit dari seorang laki-laki Anshar. Seorang laki-laki Anshar itu berkata: “Abu Qais bin al-Aslat yang termasuk orang sholeh Anshar meninggal dunia. Lalu anak laki-lakinya meminang isterinya. Maka berkatalah isteri Qais itu: “Aku anggap kamu anakku dan termasuk dari kaummu yang sholeh." Lalu wanita itu datang menghadap Nabi saw untuk menerangkan kejadiannya tadi. Maka Nabi memerintahkan untuk kembali kerumah. Lalu turunlah ayat ini sebagai keterangan mengenai ketentuan larangan mengawini ibu tiri.

Dikemukakan oleh Ibnu Sa'id yang bersumber dari Muhammad bin Ka'ib al-Qarzhi. Muhammad berkata: "Apabila seorang laki-laki meninggal dunia yang meninggalkan isteri, maka anak laki-lakinya lebih berhak terhadap ibu tirinya, hendak ia kawin atau ia kawinkan dengan orang lain terserah. Dikemukakan pula oleh Ibnu Sa'id yang bersumber dari al-Zuhri. Al-Zuhri berkata: "Ayat ini diturunkan mengenai orang-orang anshar yang apabila ada seorang laki-laki meninggal dunia, maka walinya lebih berhak memiliki isterinya dan menguasai hingga isteri yang meninggal dunia itu wafat."

\section{Sūrah an-Nisā': $23-24$}

Dikemukakan oleh Ibnu Jarir yang bersumber dari Ibnu Juraij, Ibnu
Juraij berkata: "Saya bertanya kepada 'Atha' mengenai wa halāilu abnāikum alladzina min ashlābikum, dia menjawab: "Kami pernah memperbincangkan, bahwa ayat itu diturunkan mengenai nabi Muhammad saw ketika menikahi isteri Zaid bin Haritsah (Zainab binti Jahsy)". Orang-orang musyrik berkata yang tidak-tidak. Maka turunlah ayat wa halāilu abnāikum alladzinna min ashlābikum, dan turunlah pula dua ayat yaitu surat al-Ahzāb: 4 dan surat alAhzāb: 40.

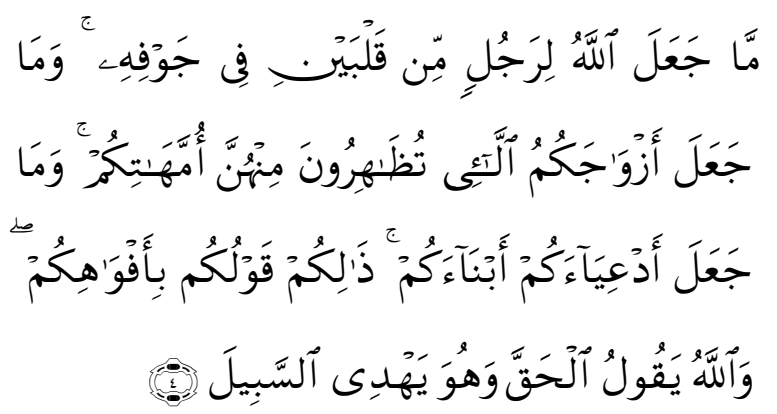

"Allah sekali-kali tidak menjadikan bagi seseorang dua buah hati dalam rongganya; dan Dia tidak menjadikan istri-istrimu yang kamu zhihar itu sebagai ibumu, dan Dia tidak menjadikan anak-anak angkatmu sebagai anak kandungmu (sendiri). Yang demikian itu hanyalah perkataanmu dimulutmu saja. Dan Allah mengatakan yang sebenarnya dan Dia menunjukkan jalan (yang benar)". (Q.S. Al-Ahzab [33]: 4.
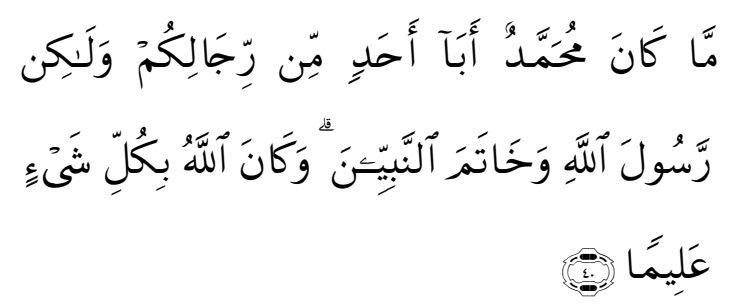
"Muhammad itu sekali-kali bukanlah bapak dari seorang laki-laki di antara kamu, tetapi Dia adalah Rasulullah dan penutup nabi-nabi. Dan adalah Allah Maha mengetahui segala sesuatu". (Q. S. Al-Ahzab [33]: 40.

Diriwayatkan oleh Muslim, Abu Dawud, al- Tirmidzi dan al-Nasa-i yang bersumber dari Abi Sa'id al-Khudhri berkata: "Kami (para sahabat) mendapatkan beberapa tawanan wanita yang sudah bersuami dari peperangan Authas. Mereka enggan digauli oleh yang berhak terhadap tawanan itu. Lalu kami bertanya kepada Nabi saw. Maka turunlah ayat ...wa al-muhshānāt min al-nisāi illa mā malakat aimānukum. Nabi saw bersabda: “...kecuali harta rampasan yang diberikan Alloh kepada kalian, maka halal bagi kita kemaluan-kemaluan mereka".

Dikemukakan oleh al-Thabarani yang bersumber dari Ibni Abbas. Ibnu Abbas berkata: "Ayat itu diturunkan pada waktu perang Hunain, ketika Alloh memberikan kemenangan kepada orang-orang Islam dan mendapatkan tawanan beberapa orang wanita ahli kitab yang sudah bersuami. Ada seorang laki-laki (muslim) apabila hendak menggauli seorang wanita dari tawanan tersebut, wanita itu selalu enggan dan berkata: "Sesungguhnya saya sudah bersuami". Lalu bertanyalah ia kepada Rasulullah saw mengeni hal tersebut. Maka turunlah ayat wa al-muhshānāt min al-nisāi sampai akhir ayat.

Firman Allah "walā junāha 'alaikum fìmā tarādhaitum bih̄ min ba'di alfaridhah". Dikemukakan oleh Ibnu Jarir yang bersumber dari Ma'mar bin
Sulaiman dari bapaknya. Bapak Jarir berkata: "orang Hadharamy menganggap bahwa orang laki-laki dibebani membayar mahar dengan harapan dapat memberatkannya (sampai tidak dapat membayar tepat pada waktunya untuk mendapatkan tambahan pemabayaran). Maka turunlah ayat walā junāha 'alaikum fìmā tarādhaitum bihī min ba'di al-faridhah.

\section{Aqwāl al-Mufassir}

Dalam tulisan ini penulis hanya memaparkan beberapa pendapat para ahli tafsir yang berkaitan dengan surat anNisā ayat $22-24$.

Imam al-Qurtubi ketika mengomentari ayat 22, menyebutkan bahwa mengawini isteri bekas ayah (ibu tiri) adalah merupakan sebuah tradisi dan kebiasaan bagi sebagian kabilah-kabilah Arab pada masa Jahiliyah tempo dulu, di mana mereka sering menggauli dan mengambil alih isteri-isteri bekas ayahnya, seperti yang pernah dialami oleh Amr bin Umayyah, di mana dia mengambil alih isteri bekas ayahnya, setelah ayah tersebut meninggal dunia, hingga mempunyai anak yang diberi nama Musafir dan Abu Mu'ith, begitu pula Sofwan bin Umayyah bin Khallaf yang mengambil isteri bekas ayahnya, yaitu Fatihah binti al-Aswad bin alMuthalib bin Asad. Kemudian Allah menurunkan ayat ini sebagai larangan untuk mengulangi perbuatan tersebut, مقتا dan فاحشة dinga ia dianggap sebagai , yaitu perbuatan yang sangat jelek dan tidak disenangi. Kecuali perbuatan itu dilakukan pada masa lalu, hal ini akan diampuni oleh Alloh dan tidak akan 
disiksa. (Abi Abdillah Muhammad bin Ahmad al-Anshari al-Qurtubi: 1965: 104)

Mufasir Kabir Imam al-Razi ketika menafsirkan ayat:

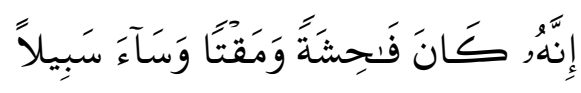

Menyatakan bahwa القبح (kejelekan) ada tiga macam dan tingkatan, yaitu عقلي, عادي darangan dalam menikahi isteri-isteri bekas ayah, terkumpul ketiga tingkatan kejelekan tersebut, yang dalam hal ini menandakan bahwa perbuatan tersebut merupakan perbuatan yang sangat keras sekali dilarang oleh Allah Swt. Kejelekan tersebut adalah:

a. فاحشَ العقلي adalah

b. قبح الشرعي adalah

c. سبح العادي adalah

Apabila ketiga kejelekan tersebut telah terkumpul menjadi satu dalam sebuah kegiatan, maka perbuatan tersebut menunjukkan kejelekan luar biasa. (Abi Bakar Ahmad bin Ali al-Razi al Jashash, tt. 24).

Menurut tafsir Fi Zhilalil Qur'an karya Sayyid Qutub dikatakan, bahwa wanita yang haram dinikahi itu sudah terkenal (masyhur) pada semua umat, baik yang masih konservatif maupun yang sudah maju. Wanita-wanita yang haram dinikahi menurut Islam adalah golongan wanita yang dijelaskan didalam surat An-Nisa ayat 22-24. Sebagiannya diharamkan untuk selamanya (yakni, selamanya tidak boleh dinikahi), dan sebagiannya diharamkan dinikahinya dalam kurun waktu tertentu. (Sayyid Qutb, 2001: 310).
Hukum diharamkannya menikahi wanita untuk selamanya terbagi menjadi beberapa bagian. Sebagian disebabkan karena hubungan nasab, sebagian disebabkan hubungan persusuan, dan sebagian disebabkan hubungan mushaharah (perbesanan). (Syekh Muhammad 'Ali Ash-Shobunny, tt: 358).

Mahram karena hubungan nasab menurut syari'at Islam ada 4 tingkatan, pertama, ushul, yakni yang menurunkan dia terus keatas. Kedua, cabang (keturunan) kebawah. Ketiga, keturunan dari kedua orang tuanya terus kebawah. Keempat, keturunan langsung dari kakek neneknya. Keturunan yang tidak langsung dari kakek nenek halal dinikahinya. Oleh karena itu, dihalalkan menikah antara anak-anak paman dengan anak-anak bibi.

Adapun yang diharamkan karena perbesanan itu ada lima, di antaranya:

1. Bekas isteri bapak.

2. Bekas isteri anak.

3. Ibu dari isteri.

4. Anak dari isteri. Keharaman ini terjadi apabila lelaki itu telah mencampuri ibunya. (Syekh Muhammad 'Ali AshShobunny, tt: 446-447).

5. Saudara wanita dari isteri. Akan tetapi, keharamannya ini dalam waktu tertentu, yaitu selama isteri masih hidup dan menjadi isteri dari lelaki yang bersangkutan. (Sayyid Kutub, 2001: 311).

Juga diharamkan menikah dengan seseorang karena adanya hubungan persusuan, Persusuan Adalah masuknya air susu seorang wanita kepada anak kecil dengan syarat-syarat tertentu. (Abdul Karim Zaidan, tt: 235) Sedangkan persusuan yang menjadikan seseorang 
menjadi mahram adalah lima kali persusuan, berdasar pada hadits dari Aisyah, beliau berkata: "Termasuk yang di turunkan dalam Al Qur'an bahwa sepuluh kali persusuan dapat mengharamkan (pernikahan) kemudian dihapus dengan lima kali persusuan." Ini adalah pendapat yang rajih di antara seluruh pendapat para ulama'. (Ibnu Hazm Ad-Dhohiri Al Muhalla bil Atsar 2/10, Mustafa Al -Adhawi Jami' ahkamun Nisa'3/47). Sebagaimana diharamkannya menikah dengan orang yang ada hubungan nasab dan perbesanan. Keharaman menikah karena hubungan ini meliputi 9 orang Mahram, yakni:

a. Ibu susuan dan ushul-nya terus keatas,

b. Anak wanita susuan dan anak-anaknya terus kebawah,

c. Saudara wanita persusuan dan anakanaknya terus kebawah,

d. Saudara wanita ayah dan saudara wanita ibu sepersusuan,

e. Ibu susuan dari isteri,

f. Anak susuan isteri,

g. Bekas isteri ayah atau kakek susuan,

h. Isteri anak susuannya terus kebawah,

i. Memadu, menghimpun antara seorang wanita dengan saudara wanita sepersusuannya, atau dengan bibi sepersusuan isterinya, atau wanita manapun yang punya hubungan kemahraman dengannya karena persusuan. (Ibnu Hazm Ad-Dhohiri Al Muhalla bil Atsar 2/10, Mustafa Al Adhawi Jami' ahkamun Nisa'3/47). Jenis yang pertama dan ketiga dari wanita-wanita mahram ini disebutkan pengharamannya dalam ayat nash di atas. Adapun selain yang diharamkan dalam surat ini, aturan pelaksanaannya disebutkan dalam hadits Nabi SAW,

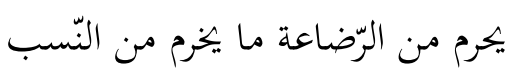

"Diharamkan karena susuan, apa yang diharamkan karena nasab." (Diriwayatkan oleh Bukhari dan Muslim).

Selain hukum diharamkannya menikahi wanita untuk selamanya, juga ada hukum dilarangnya menikahi wanita untuk sementara, diantaranya adalah sebagai berikut:

1) Mengumpulkan dua saudara perempuan sekandung, dan

2) Menikahi seorang wanita yang sedang dalam ikatan pernikahan atau wanita yang sedang berada dalam masa iddah.

Hal ini dapat dilihat dalam Firman Allah SWT:

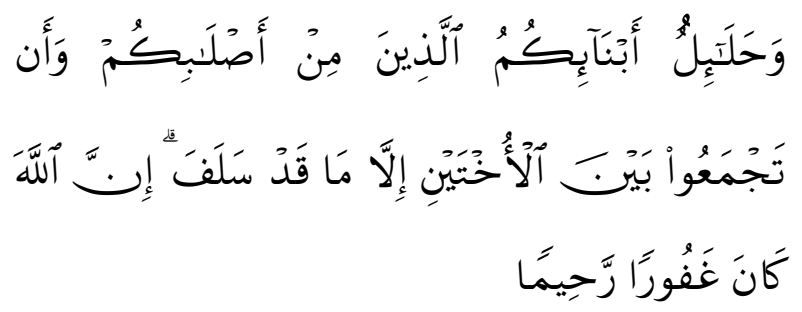

Penggalan ayat ini menegaskan dua hal yang haram dikerjakan oleh seorang muslim, yaitu menikahi istri anak atau menantu dan memadu dua orang perempuan yang bersaudara. Larangan dalam ayat ini adalah secara mutlak. Ia tidak menjelaskan syarat apa-apa, baik menantu itu telah digauli sebelum diceraikan oleh anaknya ataupun belum digauli. Oleh karena itu ayat tersebut harus pula dipahami secara mutlak. Maka sang ayah tidak boleh menikahi janda anaknya. Selanjutnya ayat ini juga menjelaskan wanita yang tidak boleh dipoligami oleh seorang laki-laki yaitu terhadap dua orang perempuan yang 
bersaudara, dan seorang perempuan dengan bibi atau tantenya.

Akan tetapi apabila laki-laki tersebut sudah bercerai dengan istrinya itu maka dia boleh menikahi saudara perempuan, bibi atau tante jandanya itu. Dalam pandangan al-Maraghi, ayat 24 surat annisā ini juga berhubungan dengan dengan kawin mut'ah (kawin temporer). Beliau menyatakan bahwa dilarangnya nikah mut'ah, karena si mutamati' (orang yang melakukan nikah mut'ah) tujuannya bukan mau kawin, tetapi hanya sekedar ingin melampiaskan nafsu seksnya semata. (Ahmad Musthafa al-Maraghi, 1974: 8).

Selanjutnya Muhmmad Quraish Shihab menyebutkan dalam tafsir AlMishbah bahwa ayat 22 dari surat an-Nisā menjelaskan keharaman seorang anak menikahi bekas istri bapaknya, walaupun pernikahan itu baru sampai pada batas pelaksanaan akad nikah. Senada dengan al-Razi, Quraish Shihab menyatakan bahwa sebenarnya adat buruk itu (menikahi bekas istri bapak) termasuk yang dikecam oleh sebagian masyarakat Jahiliyah, karena itu mereka menamai anak yang lahir dari bekas istri ayah yang dinikahi dengan مقيتا dan pernikahan itu adalah المقت, keduanya terambil dari kata مقت, yakni sesuatu yang sangat dibenci, dan dihina serta mengundang amarah. Quraish Shihab lebih lanjut menerangkan bahwa dikalangan ulama terjadi diskusi, apakah tidak terlarang seorang anak menikahi seorang wanita yang pernah melakukan hubungan seks dengan ayahnya secara tidak sah? Imam Malik dan Syafi'i berpendapat bahwa perzinaan tidak menyebabkan keharaman dan dengan demikian, bila hubungan seks itu terjadi di luar pernikahan yang sah, maka tidak ada halangan bagi anak menikahi wanita yang pernah dizinai oleh ayahnya, demikian pula ayah tidak terlarang menikahi wanita yag pernah dizinai anaknya. (Muhammad Quraish Shihab, 2002: 389).

Sementara itu Abu Hanifah, Tsauri, Auza'i, Qatadah dan Hasan berpendapat bahwa wanita yang dizinahi oleh ayahnya adalah haram untuk dinikahi oleh anaknya. Ikhtilaf di sini diakibatkan karena ketidakseragaman mereka dalam mengartikan kata نكح, dimana kata ini dapat diartikan dengan al-Wathu dan dapat juga diartikan dengan al-'aqdu. Hanafiyah mengatakan bahwa yang dimaksud dengan nikah adalah bersetubuh (al-Wathu), kemudian mereka mengatakan bahwa hakikat pengertian nikah adalah bersetubuh. Syafi'iyah menjelaskana tentang pengertian dan maksud nikah dengan al-'aqdu, dan mereka menyatakan bahwa yang menunjukkan arti nikah itu adalah akad (Muhammad 'Ali Ash-Shobunny: tt: 456). Ayat 23 dari surat an-Nisā ini menurut beliau menuturkan secara rinci, menyeluruh dan tidak mengabaikan sesuatu. Di samping itu, ayat tersebut disusun dengan amat sistematis disertai syarat dan kondisinya serta petunjuk menyangkut siapa yang haram dinikahi. Tidak dapat disangkal bahwa menyusun urutan semacam itu, walau bagi ilmuwan, adalah merupakan satu olah nalar yang tidak mudah, apalagi bila disampaikan secara spontan, sebagaimana halnya yang diterima oleh Nabi Muhammad saw. 
Dalam ayat ke 23 ini, Allah mengharamkan pernikahan dengan siapa yang masih memiliki hubungan kekeluargaan yang dekat kepadanya.

Quraish Shihab menulis bahwa beberapa Ulama menegaskan pernikahan antar keluarga dekat dapat melahirkan anak cucu yang lemah jasmani dan rohani. Menurut sementara pakar, belakangan ini ditemukan secara ilmiah bahwa pernikahan antar kerabat yang dekat berpotensi menyebabkan keturunan mudah terjangkit penyakit, cacat fisik, serta tingkat kesuburan yang rendah, bahkan mendekati kemandulan. Sebaliknya dengan pernikahan dengan orang yang tidak saling berhubungan kekeluargaan yang dekat. Tentu saja yang dimaksud adalah terutama kerabat dekat yang dilarang oleh ayat di atas, bukan semua kekerabatan, sebagaimana tidak selalu mutlak terjadi karena Nabi saw sendiri menikahkan putri beliau dengan 'Ali ibn Abi Thalib ra. Yang merupakan anak paman beliau. (Muhammad 'Ali Ash-Shobunny, tt: 392-393).

\section{Nikah/ kawin Sesuku}

Tidak dapat dipungkiri seperti kata pepatah di mana bumi dipijak di situ langit dijunjung, hal ini dapat dilihat pada masyarakat matrilinial dengan adanya larangan perkawinan sesuku, mau tidak mau masyarakat harus tunduk pada aturan adat yang sudah dibangun sejak lama. Ini akan menjadi masalah ketika agama membolehkan sementara adat melarang, di sini adat terlihat lebih kuat daripada agama, yang seharusnya agama lebih dijunjung tinggi daripada adat. Masalah perkawinan sudah diatur dalam al-Qur'ān yang mencakup rukun dan syarat perkawinan, tujuan perkawinan serta perkawinan-perkawinan yang dilarang dalam Islam. Dalam surat anNisā (4): 22- 24, wanita-wanita yang haram untuk dinikahi terbagi dua yaitu haram sementara dan haram selamanya. Surat an-Nisā ayat 22, Allah mengharamkan menikahi wanita-wanita yang telah dinikahi oleh ayahnya kecuali sebelum turunnya ayat tersebut, dalam Surat an-Nisā ayat 23, Allah memperinci wanita-wanita lain yang juga haram dinikahi, sedangkan dalam Surat an-Nisā ayat 24 Allah menambahkan larangan wanita yang haram untuk dinikahi. Sedangkan dalam adat matrilinial larangan perkawinan ditambah satu lagi yaitu larangan perkawinan sesuku.

Berdasarkan keterangan di atas dan sepengetahuan penulis dapat dilihat bahwa tidak ada larangan melakukan perkawinan yang berdasarkan tali darah dari pihak ibu maupun ayah selain yang telah dijelaskan sebelumnya. Dalam hal ini tidak ditemukan juga larangan ataupun anjuran secara tegas tentang perkawinan sesuku. Oleh karena itu tidak ada larangannya dalam al-Qur'ān maupun hadist, maka dapat disimpulkan larangan perkawinan sesuku di adat matrilinial semata-mata 'urf atau adat.

Berkaitan dengan 'urf ini menurut Mukhtar Yahya dan Faturrahman (1986: 55) terdapat kaidah ushūl al-figh yang berbunyi:

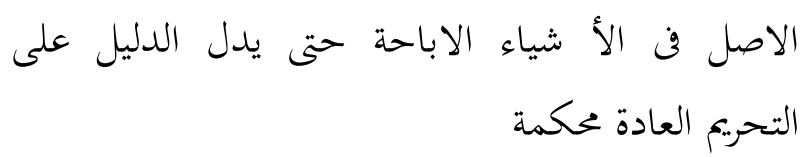

Namun demikian tidak secara otomatis 'urf/adat itu menjadi hukum, melainkan masih harus dikaji dari berbagai hal. Urf secara harfiyah yaitu suatu keadaan, ucapan, perbuatan atau 
ketentuan yang telah dikenal manusia dan telah menjadi tradisi untuk melaksanakannya atau meninggalkannya. 'urf sering disebut sebagai adat. Tetapi adat lebih umum daripada 'urf, sebab adat kadang-kadang terdiri atas adat perorangan atau bagi orang tertentu, sehingga hal ini tidak bisa dinamakan 'urf, dan kadang-kadang terdiri atas adat masyarakat. Inilah yang disebut 'urf baik bersifat umum maupun khusus. (Rachmat, 2007: 128) dan (Chaerul Uman, dkk, 2000: 159).

Para ulama fiqih membagi 'urf di antaranya sebagai berikut:

1. Dari segi cakupannya, 'urf dibagi dua:

a. Al-'urf al-'àm (kebiasaan yang bersifat umum) Yaitu kebiasaan yang berlaku umum di seluruh daerah. Misalnya dalam jual beli mobil, segala peralatan yang diperlukan untuk memperbaiki mobil, seperti tang, dongkrak termasuk dalam harga jual tanpa akad sendiri.

b. Al-'urf al-khas (kebiasaan yang bersifat khusus) yaitu kebiasaan yang berlaku pada masyarakat tertentu. Misalnya dalam jual beli jika terdapat cacat maka barang boleh dikembalikan, sedangkan di tempat lain tidak boleh dikembalikan.

2. Dari segi keabsahannya dan pandangan syara', 'urf terbagi dua:

a. Al-'urf al-sahih, yaitu kebiasaan yang berlaku di masyarakat dan tidak bertentangan dengan nāsh, tidak menghilangkan kemaslahatan dan tidak membawa mudarat bagi mereka. 'urf ini dipandang sah sebagai salah satu sumber pokok hukum Islam. Misalnya dalam masa pertunangan pihak laki-laki diperbolehkan memberi hadiah kepada wanita tetapi bukan sebagai mas kawin.

b. Al-'urf al-fäsid yaitu 'urf yang bertentangan dengan nāsh dan kaidah-kaidah dasar yang ada dalam syara', 'urf ini tidak dapat dijadikan sumber penetapan hukum. Misalnya di kalangan pedagang yang menghalalkan riba dalam hal pinjam meminjam. (Abu Zahra, tt: 27) dan (Sapiudin Shidiq, 2011: 99).

Syarat-syarat 'urf yang dapat dijadikan sumber penetapan hukum, yaitu:

1. Tidak bertentangan dengan nāsh yang qath'î.

2. 'Urf harus berlaku universal. Tidak dibenarkan 'urf yang menyamai 'urf lainnya karena adanya pertentangan antara mereka yang mengamalkan dan yang meninggalkan.

3. 'Urf harus berlaku selamanya. Tidak dibenarkan 'urf yang datang kemudian. (Ahmad Azhar Basyir, 1998: 90).

Jika dilihat dari segi cakupannya larangan perkawinan sesuku dalam adat matrilinial termasuk kategori Al-'urf alkhās (kebiasaan yang bersifat khusus) karena tidak berlaku universal, di samping itu pada saat ini sudah terjadi pertentangan antara tokoh adat dan tokoh agama. Dari segi keabsahannya larangan perkawinan sesuku dalam adat matrilinial termasuk kategori Al-'urf al-fäsid karena secara normatif bertentangan dengan nāsh dan kaidah-kaidah dasar yang ada dalam syara' serta tidak memenuhi syarat-syarat 'urf yang dapat dijadikan sumber penetapan hukum. 
Karena larangan perkawinan sesuku ini tidak terdapat secara tegas dalam $n \bar{a} s h$, maka untuk mengetahui 'urf tersebut boleh atau tidak, dapat dilihat dari aspek mashlahah dan madharat dengan mempertimbangkan maqasid al-syari'ah.

Maqasid al-syari'ah bermaksud mencapai, menjamin dan melestarikan kemaslahatan bagi umat manusia, khususnya umat Islam. Dalam maqasid al-syari'ah terdapat tiga skala prioritas yang berbeda tetapi saling melengkapi yaitu: al-daruriyyat, alhajjiyat dan al-tahsiniyyat. Daruriyyat (tujuan-tujuan primer) yaitu tujuan yang harus ada, jika tidak maka akan mengakibatkan hancurnya kehidupan secara total. Daruriyyat ini ada lima: agama, jiwa, akal, harta dan keturunan. Hajjiyat (tujuan-tujuan sekunder) yaitu sesuatu yang dibutuhkan manusia untuk mempermudah mencapai kepentingankepentingan yang termasuk ke dalam ketegori daruriyyat. Sedangkan tahsiniyyat (tujuan-tujuan tertier) yaitu sesuatu yang kehadirannya bukan niscaya maupun dibutuhkan, tetapi bersifat akan memperindah proses perwujudan kepentingan daruriyyat dan hajjiayat. (Abu Zahrah, tt: 370).

Dalam pemahaman penulis larangan perkawinan sesuku tidak termasuk ke dalam kategori daruriyyat, tetapi hanya masuk kategori hajiyyat karena dibutuhkan masyarakat matrilinial untuk mempermudah mencapai kesejahteraan rumah tangga. Tidak adanya larangan perkawinan ini tidak akan mengakibatkan hancurnya kehidupan masyarakat. Oleh karena itu perkawinan sesuku hukumnya mubah (boleh).

Hal ini dapat dilihat dari ketentuan adat matrilinial yang menyebutkan bahwa adat tidak pernah mengharamkan menikah sesuku, tetapi hanya melarang. Antara mengharamkan dengan melarang itu berbeda. Menikah sesuku itu berarti hukumnya halal/boleh, tetapi masyarakat matrilinial tidak mengerjakannya karena beberapa hal dan pertimbangan. Menurut hukum adat Batak yang hubungan kekerabatannya bersifat asymmettrisch connubium, melarang terjadinya perkawinan antara pria dan wanita yang satu marga. Perkawinan harus dilaksanakan manunduti atau melakukan perkawinan berulang searah dari satu sumber bibit, pihak penerima darah (boru) dianjurkan dan dikehendaki untuk tetap mengambil darah dari pemberi darah (hula-hula). Adalah ideal sifatnya seorang pria dapat kawin dengan wanita anak paman saudara laki-laki dari ibu (tulang). Keadaan ini berlaku juga di Timor tetapi tidak dibenarkan kawin antara anak bersaudara ibu.

Demikian pula di Rejang, apabila dilakukan perkawinan sesuku berakibat pecah suku, atau di daerah Pasemah (Sumsel) disebut merubuh Sumbai. Pelanggaran terhadap larangan ini dijatuhi hukuman denda adat yang harus dibayar kepada para Prowatin Adat dengan cara menyembelih ternak agar dapat terhindar dari kutuk arwah-arwah ghaib. Di kalangan masyarakat Lampung Beradat Perpadun seorang pria dilarang melakukan perkawinan dengan anak saudara lelaki ibu (Kelama) tetapi termasuk perbuatan mengembalikan bibit (Ngulehken Mulan) apabila seorang pria melakukan perkawinan dengan wanita anak dari saudara perempuan ayah (Ngakuk Menulung). Setelah masuknya ajaran Islam larangan kawin dengan wanita anak Kelama (Tulang-Batak) hanya dianggap perbuatan tercela. Hal itu 


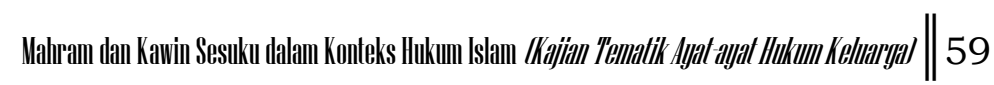

dilakukan sebelum upacara perkawinan, si wanita harus dinaikan di atas langitlangit atap rumah karena takut Tulah (takut tidak direstui ghaib). Di Bali dilarang terjadi perkawinan antara saudara wanita suami dengan saudara pria isteri (make dengan ngad) karena perkawinan demikian akan mendatangkan bencana (panes). Di Jawa tidak dibolehkan kawin antara pria dan wanita yang bersaudara kandung ayahnya, begitu juga dilarang kawin bersaudara bisan dan dilarang kawin apabila ibu yang pria lebih muda dari ibu si wanita (Tolib Setiady, 2009: 264).

Menikah sesuku menurut logika hukum matrilinial terutama Minangkabau tidak baik. Sanksinya jika dilanggar adalah sanksi moral, dikucilkan dari pergaulan. Bukan saja pribadi orang yang mengerjakannya, tapi keluarga besar pun mendapat sanksinya, membuat aib karena perangai kita. Selain itu juga beredar mitos di Minangkabau yang sudah diyakini turun-temurun bahwa nikah sesuku akan membawa petaka dalam rumah tangga nantinya. Beberapa alasan mengapa masyarakat Minangkabau melarang keras pernikahan sesuku.

1. Pelopor Kerusakan dalam Kaum

2. Mempersempit Pergaulan

3. Menciptakan Keturunan yang Tidak Berkualitas.

4. Mengganggu Psikologis Anak.

5. Kehilangan hak Secara Adat.

6. Membawa Kerugian Materi.

(http://sumbar.co/budaya/alasanmengapa-pernikahan-sesuku-dilarang-diminangkabau/).

Menyikapi larangan nikah sesuku dalam adat matrilinial penulis berpendapat bahwa penerapan hukum syar'i perlu disesuaikan dengan kesiapan masyarakat untuk menerimanya. Karena itu, penerapan ini membutuhkan pemahaman terhadap apa yang dikenal dengan istilah fiqhul waqi' dan fiqhud dakwah. Bila penerapan hukum pada masyarakat di suatu tempat akan menimbulkan gejolak, atau sanksi yang memberatkan, maka penerapan itu bisa ditanguhkan sampai masyarakat memiliki kesiapan untuk itu. Dalam adat minang contohnya, sebenarnya ada aturan-aturan yang baku dan tidak bisa diubah, seperti dalam pepatah minang "Nan Indak lakang dek paneh, nan indak lapuak dek ujan". Di antaranya adalah seperti kepatutan menurut agama, menurut peri kemanusiaan, menurut hukum alam yang didasarkan pada kodrat ilahi, atau menurut tempat dan waktu. Aturan ini dikenal dengan istilah adat nan sabana adat (adat yang sebenarnya).

Selain itu ada juga aturan-aturan yang bisa berubah-ubah berdasarkan pada kesepakatan. Sebagaimana dalam pepatah "Nan elok dipakai jo mufakat, nan buruak dibuang jo hetongan, Adat habih dek bakarilahan." Aturan ini dikenal dengan istilah adat nan diadatkan (adat yang diadatkan).

Ada juga kebiasaan yang sifatnya adalah peribadi atau individu yang bisa ditambah dan dikurangi atau ditinggalkan. Hal ini dikenal dengan istilah adat nan teradat (adat yang teradat). Terakhir adalah adat yang sifatnya kelaziman yang berubah-ubah mengikuti alur yang ada pada masingmasing tempat. Seperti kesenian, perhelatan dll. Hal ini dikenal dengan istilah adat istiadat. 
60

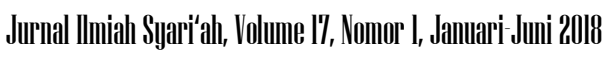

Keempat kelompok dari adat ini merupakan modal dasar bagi para reformis untuk melakukan pembaharuan adat di masa mendatang sesuai dengan aturan syara' yang sempurna. Peluang ini cukup terbuka untuk dialakuan sebagaimana yang pernah dilakukan oleh orang-orang sebelumnya. Apalagi adat minang memiliki falsafah dasar "adat basandi syara', syara' basandi kitabulloh" (adat berlandaskan syari'at dan syari'at berlandaskan kitabulloh). Namun perlu kesabaran dalam memberikan pemahaman kepada masyarakat sesuai dengan bahasa yang mereka pahami. Sehingga mereka memiliki kesiapan untuk menyepakati aturan yang sesuai dengan syara' yang menjadi dasar bagi adat minang. Wallahu a'lam.

\section{KESIMPULAN}

Setelah menguraikan ayat-ayat tersebut di atas, dapatlah ditarik beberapa istinbath hukum, antara lain:

1. Bahwa perempuan yang haram dinikahi terbagi kepada dua golongan, yaitu:

a. Hubungan Keluarga (نسبية) yang terdiri dari tujuh macam, yaitu:

1) الأمهات (Ibu)

2) البنات (anak-anak)

3) الأخوات (saudara)

4) العمات (bibi dari ayah)

5) الخالات (bibi dari ibu)

6) بنات الأخ (anak saudara laki-laki)

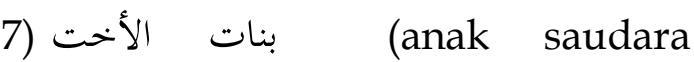
perempuan) b. Hubungan mertua dan susuan Bagian ini terdiri dari tujuh macam pula, yaitu:

1) (ibu yang menyusui)

2) (saudara satu susuan)

3) أمهات النساء (ibu mertua)

4) الربائب (anak tiri)

5) حلائل الأبناء (istri anak kandung)

6) الجمع بين الأختين (memadu di antara dua saudara)

7) ما نكح أباؤكم (bekas istri ayah).

Larangan perkawinan sesuku tidak termasuk ke dalam kategori daruriyyat, tetapi hanya masuk kategori hajiyyat karena dibutuhkan masyarakat matrilinial untuk mempermudah mencapai kesejahteraan rumah tangga. Tidak adanya larangan perkawinan ini tidak akan mengakibatkan hancurnya kehidupan masyarakat. Oleh karena itu perkawinan sesuku hukumnya mubah (boleh).

\section{DAFTAR KEPUSTAKAAN}

Abdul Karim Zaidan, Al Mufashol fi Ahkamil Mar'ati wa Baitil Muslim fi Syari'ati Islamiyyah jilid 3

Abi Abdillah Muhammad bin Ahmad alAnshari al-Qurtubi, al-Jāmi' $l i$ Ahkāmi al-Qurān Kairo: Dar al-Kitab al-'Arabi, 1965, J.5

Abi Bakar Ahmad bin Ali al-Razi al Jashash, Ahkām al-Qur ān, Kairo: Isa al-Babi al-Halabi, tt. J. 10 
Abu Zahra, Ushul Figh, Damaskus: Daar al-Fikr, tt.

Ahmad Azhar Basyir, Hukum Adat Bagi Umat Islam, Yogyakarta: Nurhidayah, 1998

Ahmad Musthafa al-Maraghi, TafsirnalMaraghi, Kairo: Musthafa al-Babi alHalabi, 1974, J. 5

Ahmad Warson Munawwir, Al-Munawwir Kamus Indonesia - Arab, (Surabaya: Pustaka Progressif, cet.14, 1997

Amiur Nuruddin, Hukum Perdata Islam di Indonesia, (Studi Kritis Perkembangan Hukum Islam dari Fikih, UU No. 1/1974 sampai KHI), Jakarta: Prenada Media, 2004

Amir Syarifuddin, Hukum Perkawinan Islam di Indonesia Antara Figh Munakahat dan Undang-undang Perkawinan, Jakarta: Kencana, 2007

Chaerul Uman, dkk, Ushul Fiqih 1, Bandung: Pustaka Setia, 2000

Ibnu Hazm Ad-Dhohiri Al Muhalla bil Atsar 2/10, Mustafa Al-Adhawi Jami' ahkamun Nisa'3/47.

Imam Jalaludin al-Suyuti, Asbāb al-Nuzūl, Beirut: Muassasah al-Kutub alTsaqofiyah, $1422 \mathrm{H}$
Muhammad Khasyad, Fiqhu Nisā' fi Wuduil Madhahibil 'Arba'ah, AlQohirah: Darul Kurub AlMu'așiroh, 1994

Muhammad Quraish Shihab, Tafsir alMishbah: Pesan, Kesan dan Keserasian al-Qur'an, Jakarta: Lentera Hati, 2002

Rachmat Syafe'i, Ilmu Ushul Fiqih Bandung: Pustaka Setia, 2007

Sapiudin Shidiq, Ushul Fiqh, Jakarta: Kencana Prenada Media Group, 2011

Sayyid Qutb, Tafsir Fi Zhilalil Qur'an, Jakarta: Gema Insani Press, 2001, Jilid 2

Syekh Muhammad 'Ali Ash-Shobuny, Rowai'ul Bayan Tafsir Ayat al-Ahkam min al-Qur'an, Jakarta: Darul Kutub al-Islamiyah, t.th, Juz 1

Tolib Setiady, Intisari Hukum Adat Indonesia (Dalam Kajian Kepustakaan), Bandung: Alfabeta, 2009. 